Нефтегазовое дело. 2021. Т. 19, № 5. С. 75-83. ISSN 2073-0128 (print)

Petroleum Engineering. 2021. Vol. 19, No. 5, P. 75-83. ISSN 2073-0128 (print)

Original article

UDC 54.061/54.062

doi: $10.17122 /$ ngdelo-2021-5-75-83

\title{
A NEW APPROACH TO THE ANALYSIS OF CLAY MINERALS IN ROCKS BY X-RAY SCATTERING
}

\author{
Vil D. Sitdikov' , Artem A. Nikolaev', Ekaterina A. Kolbasenko', \\ Artem K. Makatrov' ${ }^{1}$ Andrey V. Malinin'
}

${ }^{1} \mathrm{RN}$-BashNIPIneft LLC, Ufa, Russia

\section{Corresponding author}

Vil D. Sitdikov, SitdikovVD@bnipi.rosneft.ru

\begin{abstract}
Currently, the identification and quantification of clay minerals content by X-ray phase analysis (XPA) is the most important task in oil and gas field development, as well as understanding the genesis of the rock. At the same time, the choice of modes for recording diffraction patterns of clay minerals and its further processing using modern approaches is a rather difficult, but urgent problem. In this regard, this paper reports on a new approach that enables evaluating qualitatively and quantitatively, with improved statistics, clay minerals in rocks by X-ray phase analysis. Unlike conventional XPA methods that use a «divergent» ray (Bragg-Brentano geometry), this method analyzes an X-ray diffraction (XRD) pattern obtained by «averaging» a series of XRD patterns measured at different azimuthal angles of inclination of the air-dried mount with respect to the incident «parallel» X-ray beam. First, this method was well tested for a pelitic fraction where kaolinite prevailed, with a small content of illite, mixed-layer formations, chlorite and montmorillonite. It was found that the modified approach to the XRD patterns measurement enabled evaluating more accurately the weight fraction of clay minerals, and revealing the clay minerals with a small content that could not be detected by conventional XPA. In particular, as a result of applying a new approach to the pelite fraction, in addition to kaolinite, illite and mixed-layer formations, chlorite and montmorillonite were found. Scanning electron microscopy (SEM) and $\mathrm{X}$-ray fluorescence (XRF) analysis were used to validate the credibility of the obtained results. Theoretical estimates of the content of clay minerals based on X-ray fluorescence data showed improved convergence with the results of the modified XRF.
\end{abstract}

\section{Keywords}

clays, X-ray scattering,

qualitative phase analysis

\section{For citation}

Sitdikov V.D., Nikolaev A.A., Kolbasenko E.A., Makatrov A.K., Malinin A.V. A New Approach to the Analysis of Clay Minerals in Rocks by X-Ray Scattering // Нефтегазовое дело. 2021. T. 19, № 5. С. 75-83. https://doi.org/10.17122/ngdelo-2021-5-75-83. 
Научная статья

\title{
НОВЫЙ ПОДХОД К АНАЛИЗУ ГЛИНИСТЫХ МИНЕРАЛОВ В ГОРНЫХ ПОРОДАХ МЕТОДОМ РЕНТГЕНОВСКОГО РАССЕЯНИЯ
}

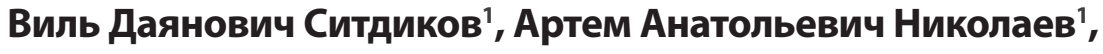 \\ Екатерина Алексеевна Колбасенко ', Артем Константинович Макатров ${ }^{1}$, \\ Андрей Владимирович Малинин ${ }^{1}$
}

${ }^{1} \mathrm{OOO}$ «РН-БашНИПИнефть», Уфа, Россия

Автор, ответственный за переписку

Виль Даянович Ситдиков, SitdikovVD@bnipi.rosneft.ru

\begin{abstract}
Аннотация. В настоящее время идентификация и количественная оценка содержания глинистых минералов методом рентгенофазового анализа (РФА) является важнейшей задачей при разработке нефтяных и газовых месторождений, а также понимания генезиса породы. При этом выбор режимов съемки дифрактограмм глинистых минералов и ее дальнейшая обработка с использованием современных подходов, являются достаточно непростой, но актуальной проблемой. В этой связи данная статья посвящена новому подходу, позволяющему с улучшенной статистикой качественно и количественно оценить глинистые минералы в горных породах методом РФА. В отличие от традиционных методов РФА, в которых используется «расходящийся» луч (геометрия Брэгг-Брентано), в данном методе анализируется дифрактограмма, полученная в результате «усреднения» серии дифрактограмм, полученных при различных азимутальных углах наклона воздушно-сухого препарата относительно падающего «параллельного» рентгеновского пучка. Данный метод хорошо апробирован к случаю пелитовой фракции, в которой преобладает каолинит с незначительным содержанием иллита, смешаннослойных образований, хлорита и монтмориллонита. Установлено, что модифицированный подход к съемке дифрактограмм позволяет точнее оценить весовую долю глинистых минералов, а также выявить глинистые минералы малого содержания, которых не удается обнаружить при традиционном РФА. В частности, в результате применения нового подхода к пелитовой фракции, помимо каолинита, иллита и смешаннослойных образований, были обнаружены хлорит и монтмориллонит. Для подтверждения достоверности полученных результатов были использованы методы растровой электронной микроскопии и рентгенофлуоресцентного анализа. Теоретические оценки содержания глинистых минералов, основанные на данных рентгенофлуоресцентного анализа, показали улучшенную сходимость с результатами модифицированного РФА.
\end{abstract}

\section{Ключевые слова}

глинистые минералы, рентгеновское рассеяние, количественный фазовый анализ

\section{Для цитирования}

Sitdikov V.D., Nikolaev A.A., Kolbasenko E.A., Makatrov A.K., Malinin A.V. A New Approach to the Analysis of Clay Minerals in Rocks by X-Ray Scattering. Neftegazovoe delo - Petroleum Engineering, 2021, Vol. 19, No. 5, pp. 75-83. https://doi. org/10.17122/ngdelo-2021-5-75-83. 


\section{Background}

At present, the use of traditional geological methods (optical microscopy, geophysical and petrophysical methods) for the study of rocks with clay minerals does not yield sufficiently accurate results in terms of their identification and quantitative evaluation, since argillaceous varieties are composed of tiny particles with a size normally not exceeding $1 \mu \mathrm{m}$. A reliable geological interpretation of the results of the study of clay minerals is necessary for understanding the genesis of the rock, as well as for determining the conditions of post-sedimentation changes, which are directly determined by the specific features of the formation of certain clayey varieties contained in the sediments.

A correct identification and subsequent evaluation of the content of clay minerals is an essential factor in the development of oil and gas fields. In particular, during the interaction of clay rocks with drilling mud in the drilling of wells, swelling of clay minerals occurs which leads not only to a change in volume, but also to an increase in the internal stresses in the rock. This process is accompanied by the clogging of the reservoir, which results in a decreasing producible oil index. This fact needs to be taken into account when planning field development since it represents an important factor that determines wellbore stability. Violation of this condition results in cavings, cavern formation or borehole narrowing as a consequence of plastic deformation induced by the sticking of the drilling mud. All the above said indicates that it is necessary to determine, quantitatively and qualitatively, the ratio of clay minerals in a formation in order to evaluate the damage and economically justify the expediency of expensive corrective measures. Thus, the identification and quantitative evaluation of clay minerals is one of the most complex and relevant tasks in minerology due to a high degree of dispersion of clay particles.

One of the principal methods for the diagnostics of clay minerals is X-ray phase analysis (XPA). The XPA method enables determining with sufficient accuracy the mineral composition of a rock, and its up-to-date capabilities help to calculate their quantitative ratio [1]. It is known that for a more accurate identification of clay minerals, the same sample needs to be measured both in the air-dried condition and in the conditions after saturation with ethylene glycol [2]. Since some clay minerals have approximately similar reflections, e.g. illite and mixed-layer il- lite-smectite, the saturation of a sample with ethylene glycol (glycerol) enables resolving the superimposed reflections, e.g. at a scattering angle of $\sim 8.6^{\circ}$ (at $\mathrm{Cu}$ radiation), and thus detect swelling minerals.

In the quantitative evaluation of the fraction of minerals, an important role is played by the choice of the method for the analysis of X-ray diffraction (XRD) patterns. In particular, in the Reference Intensity Ratio (RIR) method the volume fraction of clay minerals strongly depends on the selected card stored in a diffractometric database (e.g., ICDD PDF-2). For instance, in the diffractometric database ICDD PDF-2 (from 2012) the RIR value for quartz varies from 1.2 to 5.1, and for calcite - from 1.4 to 3.5. Therefore, depending on the selected card of a mineral (i.e. the RIR value), the same XRD pattern, when processed, may yield different data about the ratio of minerals.

The Rietveld method, relying on the atomicstructural parameters of the phases under study, is considered to be one of the most accurate methods for the processing of XRD patterns in XPA [3]. In this method, after a qualitative phase analysis is performed and the corresponding phases are selected, such parameters are optimized as the scale factor, the lattice constant, the broadening of reflections, the crystallographic texture parameters, and the correction of sample displacement in terms of depth and scattering angle. At each stage of XRD pattern refinement, the above-mentioned parameters may be either optimized or recorded. For example, in the paper [4] this method was applied to study ordered and disordered illite-smectite minerals. It was also shown that the results of the XRD pattern modelling were greatly affected by an incorrect choice or recording of certain parameters in the successive stages of refinement [4].

Thus, a successful identification and quantitative evaluation of clay minerals is determined, on the one hand, by the procedure of the pelitic fraction sample preparation, and on the other hand, by the conditions under which XRD patterns are measured and the choice of the analysis method. Therefore, the aim of the present study is to further develop the procedures for the identification and quantitative evaluation of clay minerals using a new approach that consists in the application of the most efficient modes of XRD pattern measurement. To confirm the correctness of the XPA results, the contents of clay minerals were theoretically evaluated by scanning electron microscopy (SEM) and X-ray fluorescence (XRF). 


\section{Experimental and methods}

To carry out XPA in a rock sample containing clay minerals, the total mineral composition was first determined. To determine the general mineral composition of a rock, first, a rock sample of $10 \mathrm{~g}$ was taken from the general mass of about $100 \mathrm{~g}$ by quartering. Then, the selected sample was subjected to ball milling in a Retsch MM 400 vibration mill at a frequency of $30 \mathrm{~Hz}$ for $2 \mathrm{~min}$. Further, from the produced rock powder a sample of about $1 \mathrm{~g}$ was taken by quartering and subjected to XPA. From the remaining powder, a powder sample of about $1 \mathrm{~g}$ was taken, also by quartering, and subjected to XRF.

The clay fraction was extracted from the rock in the following manner. $90 \mathrm{~g}$ of the rock was ground in a mortar to sizes of $0.1-3.5 \mathrm{~mm}$ and placed into a $600 \mathrm{ml}$ glass. The ground sample was poured over with distilled water, $20 \mathrm{ml}$ of liquid calgon was added and placed in an ultrasonic bath for $20 \mathrm{~min}$. Then, filtering through a sieve $(0.1 \mathrm{~mm})$, the sample was poured into $250 \mathrm{ml}$ glasses and held for $5 \mathrm{~h}$. As a result, a transparent or semi-transparent water column formed above the settled rock layer. Without stirring up the sediment, the water was carefully drained, placed into a centrifuge and rotated at a frequency of $50 \mathrm{~Hz}$ for $15 \mathrm{~min}$. The upper layer of the water was then drained, and the remaining suspension was applied onto a glass slide and left to dry at room temperature.

In accordance with the new approach, for performing the XPA the XRD patterns were measured using a Rigaku Ultima IV diffractometer with a parallel beam geometry of the goniometer (Figure 1). The ray parallelism was ensured by the Göbel mirror in the $\mathrm{CBO}$ system and a thin collimator with a divergence angle of $0.5^{\circ}$. In or- der to enhance the diffraction maxima from small-content clays, the radiation area was increased by using slits vertically $(10 \mathrm{~mm})$ and horizontally $(10 \mathrm{~mm})$ limiting the ray in the incident and reflected beam. In addition, when measuring the XRD patterns an increased exposure time of $5 \mathrm{~s}$ per point was used. The spectral resolution of the system was increased by placing the tube focus and the detector's receiving slit at the maximum distance from each other allowed by the device, equal to $285 \mathrm{~mm}$.

To produce a series of the XRD patterns of pelitic fraction, a multifunctional texture attachment was used that was inclined after each measurement to an angle $\alpha$ of $0^{\circ}$ to $70^{\circ}$ with a step of $10^{\circ}$ with respect to the $\mathrm{Z}$ axis (Figure 1). As a result of such an approach, a series of eight XRD patterns were obtained. Then, an averaged XRD pattern to be used for the XPA was obtained from the XRD pattern series by means of summing. The XRD patterns for the general mineral composition and for the pelitic fractions were measured with $\mathrm{CuK} \alpha$ radiation generated at a voltage of $40 \mathrm{kV}$ and $40 \mathrm{~mA}$ in a range of $4^{\circ}$ to $60^{\circ}$ with a step of $0.02^{\circ}$. Qualitative phase analysis was performed using the PDXL software (ver. 1.8), and quantitative calculations were performed using the TOPAS software (ver. 4.2).

The elemental analysis of the rocks was performed by the GeolQuant method using an ARL Perform X 4200 W X-ray fluorescence spectrometer. The powder sample collected by quartering was pressed using boric acid on a Fluxana Vaneox PR-40 automated press. Cellulose was used as a binding material. The pressing force was $20 \mathrm{kN}$, and the holding time was $5 \mathrm{~s}$. The contents of the rock-forming oxides were calculated using the OXSAS software.

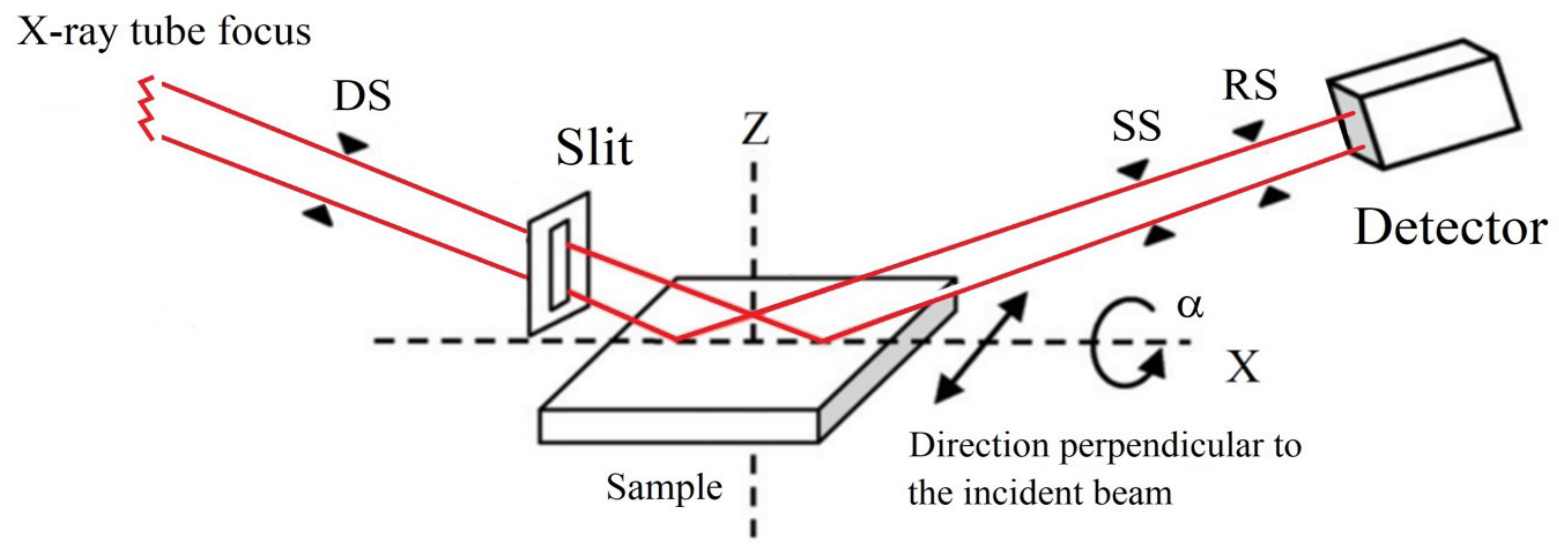

DS — divergence slit; SS — scattering slit; RS — receiving slit; $\alpha$ — azimuthal angle

Figure 1. Measurement principle according to the modified approach 
The microstructural studies of the rocks and their mineral compositions were carried out using a FEI Thermo Scientific Q250 scanning electron microscope. The main characteristics of the measurement of the samples under study were as follows: accelerating voltage $10 \mathrm{kV}$, beam diameter $3 \mu \mathrm{m}$, focal length $9.5-11 \mathrm{~mm}$, pressure $10^{-4}-10^{-2} \mathrm{~Pa}$. Prior to the electron microscopic and microprobe studies, the samples were subjected to extraction in an alcohol-benzene solution in a Soxhlet apparatus and then vacuum-died in a vacuum drying oven (at a temperature of $30^{\circ} \mathrm{C}$ ) for $12 \mathrm{~h}$. The produced rock chips, prior to observation in the electron microscope, were glued to the specimen holder with conductive carbon glue. Then, to remove from the sample surface the charge produced by the interaction of the electron beam with the sample surface, they were sprayed with a thin conductive gold coating, $15 \mathrm{~nm}$ in thickness. The spraying was performed in the Safematic CCU-010 apparatus.

\section{Results}

This section briefly presents the results of studying the microstructure by scanning electron microscopy, the total mineral composition by $\mathrm{XRD}$ and X-ray fluorescence analysis.

The rock in sample is composed predominantly of clay microflakes of sheet-like and tabular shapes and in the form of clots with an average size of $6 \times 7 \mu \mathrm{m}$, with prevailing kaolinite and illite varieties (Figure 2, $a, b$ ). Also observed in the rock are fine-aggregate cryptocrystalline siliceous minerals of an irregular elongated shape with an average size of $6 \times 12 \mu \mathrm{m}$. In some places, the siliceous minerals have recrystallized with the formation of quartz microcrystals of oval isometric shapes with a size up to $8 \times 14 \mu \mathrm{m}$. Irregularly distributed, single crystals of anatase are found in the rock.

Results of XRF analysis (wt. \%: $\mathrm{SiO}_{2}-$ 49.50, $\mathrm{Al}_{2} \mathrm{O}_{3}-33.93, \mathrm{TiO}_{2}-1.14, \mathrm{Fe}_{2} \mathrm{O}_{3}-$ 1.04, $\mathrm{K}_{2} \mathrm{O}-0.77, \mathrm{Na}_{2} \mathrm{O}-0.26, \mathrm{CaO}-0.17$, $\mathrm{MgO}-0.26$ ) showed that the main rock-forming elements for the rock are silicon and aluminum oxides. A small amount of potassium oxide indicates a relatively low content of illite.

Quantitative X-ray phase analysis showed that the sample contains mainly kaolinite with a weight fraction of $88.5 \%$, as well as quartz with a content of $6.3 \%$, illite $-2.9 \%$, and anatase $-2.3 \%$.

\section{Modified procedure for the X-ray phase analysis of clays}

This section discusses the results of extended clay analysis of the pelite fraction using traditional and modified XRF. The advantages and disadvantages of traditional XRF are first discussed. Further, a modified X-ray phase analysis technique is applied to the same pelite fractions.

Figure 3, $a$ shows the XRD pattern of pelitic fraction, obtained by conventional measurement. Qualitative XPA demonstrates that mainly the kaolinite and illite phases are present in the pelitic fraction (Figure 3,a).

For the conveniency of analysis, the respective peak curves for kaolinite (blue lines) and illite (green lines) were superimposed on the XRD pattern (Figure 3,a). The positions of the set of the diffraction maxima and the corresponding kaolinite intensities were plotted on the basis of the PDF-2 database (card No. 00-002-0105).

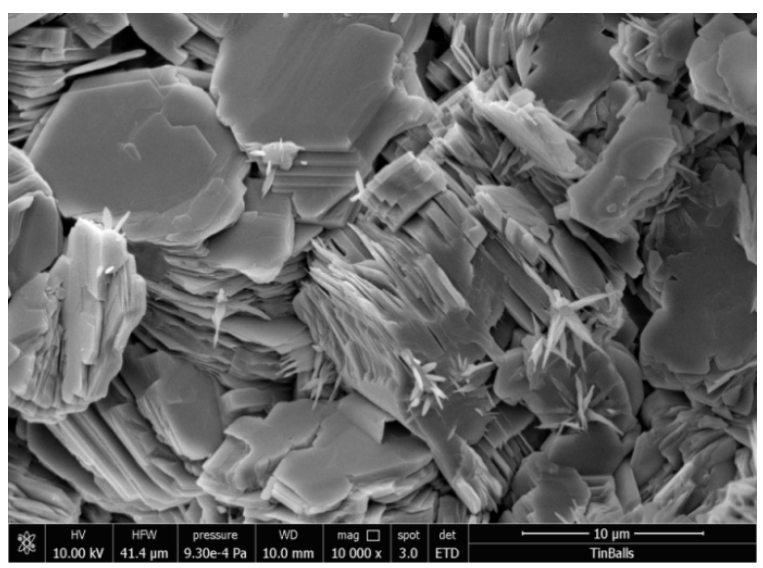

a)

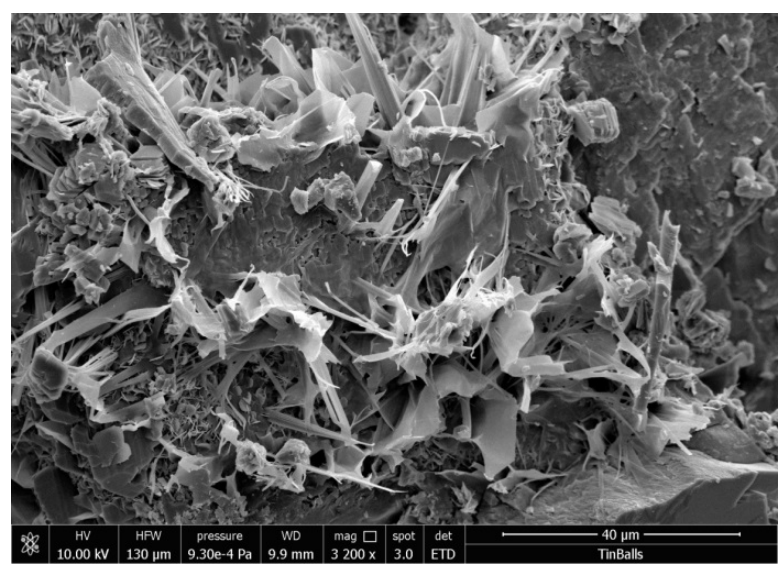

b)

Figure 2. SEM images of the microstructure confirming the presence of kaolinite (a), illite — mixed-layer formations (b) 


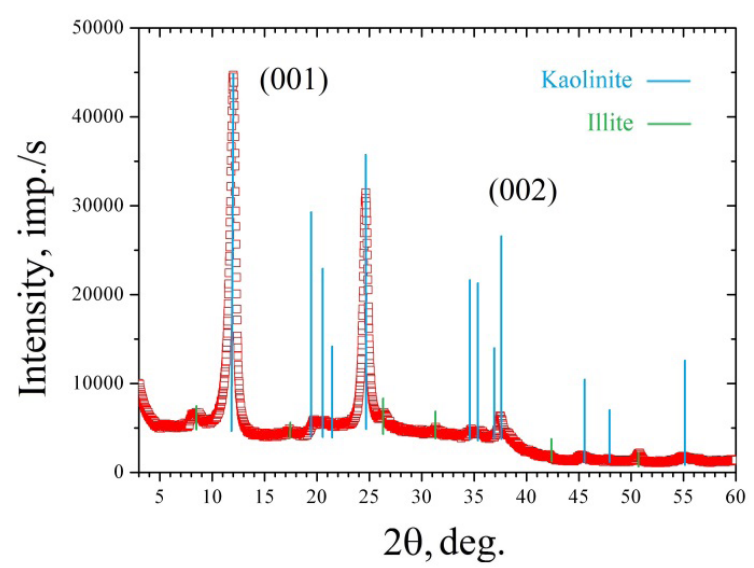

a)

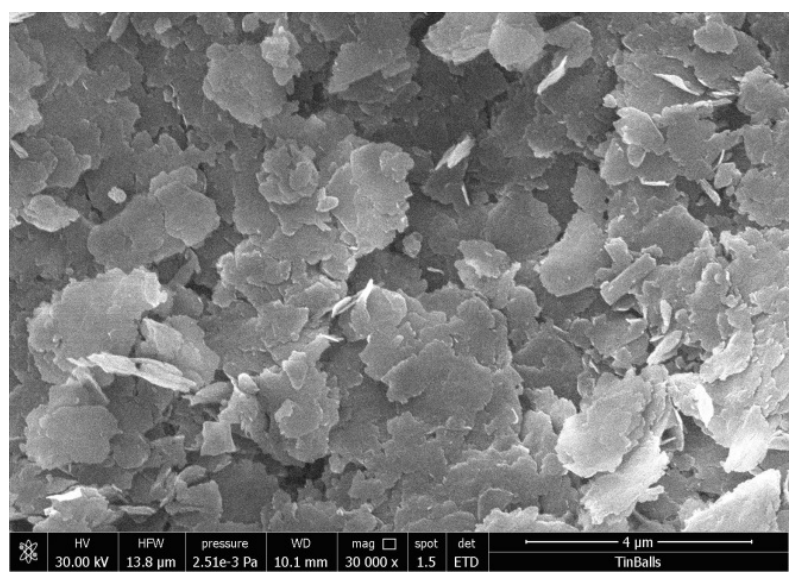

b)

Figure 3. General view of the XRD pattern (a) and the SEM image of the pelitic fraction extracted from the rock (b)

It can be seen that the tabular data for the position of the diffraction maxima for angle $2 \theta$ for illite and kaolinite are in good agreement with the positions of reflections in the XRD pattern (Figure $3, a$ ). However, the tabular data for the intensities of the diffraction maxima for kaolinite (set of blue lines) differ considerably from the experimental data (Figure 3, $b$ ).

Quantitative XPA demonstrates that kaolinite with a volume fraction of $92.3 \%$ is prevalent in the pelitic fraction. The illite content is $5.1 \%$. In addition, mixed-layer illite-smectite (MLIS) formations were found in a small quantity $(2.6 \%)$. When processing the XRD patterns, crystallographic texture was taken into account in the framework of the March-Dollase approach for a family of $\{001\}$ planes. Thus, when processing an XRD pattern obtained by conventional measurement, it is necessary to refine the crystallographic texture parameters and the scale factor.

To improve the results of the X-ray phase analysis of the clays, in compliance with the new approach the pelitic fraction was first measured in a parallel beam at different azimuthal angles $\alpha$ of inclination with respect to axis Z (Figure 1). As a result, a series of XRD patterns were obtained, shown in Figure 4, $a$.

At an inclination angle $\alpha$ of $0^{\circ}$ the XRD pattern is similar to that obtained by conventional measurement (Figure 4, a). However, with increasing azimuthal angle $\alpha$ of inclination, the intensities of kaolinite's reflections (001) and (002) become suppressed, while the intensities of the diffraction maxima (100), (010) and (111) grow

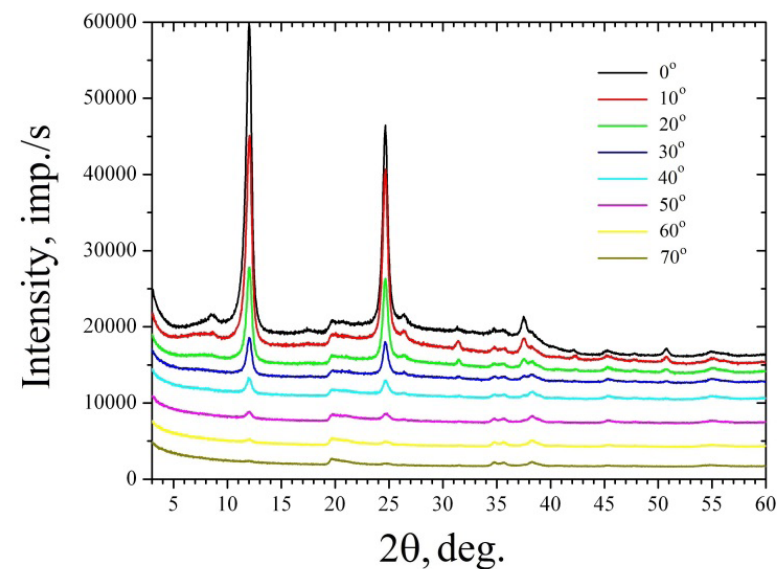

a)

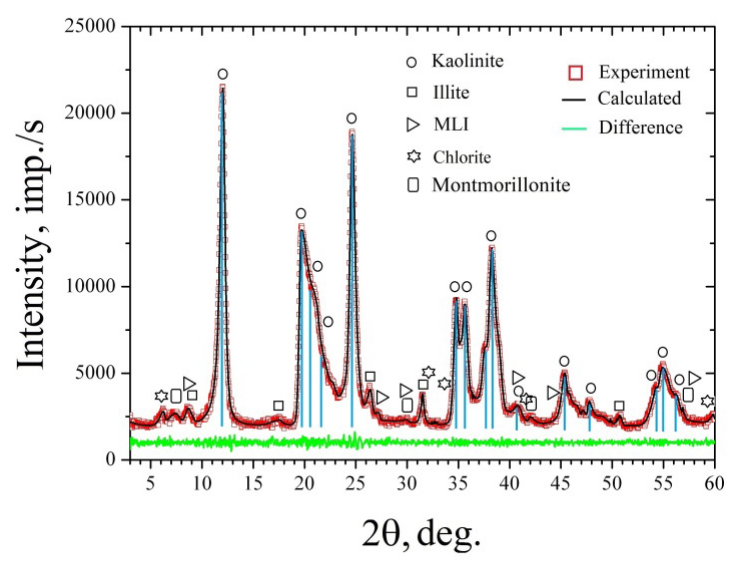

b)

Figure 4. Series of XRD patterns obtained when measuring a pelitic fraction with different inclination angles $\alpha$ (a), the averaged and modelled XRD pattern (b) 
(Figure $4, a$ ). Since only one XRD pattern needs to be processed in XPA, an «averaged» XRD pattern was obtained by algebraic summation of the series of XRD patterns. The averaged XRD pattern is shown in Figure $4, b$. Unlike the XRD pattern obtained by conventional measurement (Figure 3,a), in the new approach not only the positions but also the intensities of kaolinite's diffraction reflections are in good agreement with those (blue lines) (Figure 4,b) taken from card No. 00-002-0105 of the PDF-2 database.

The mentioned correspondence significantly simplifies the processing of the XRD pattern, since no additional stages of refinement are required for individual reflections in terms of crystallographic texture and scale factor. The results from the modelling of the averaged XRD pattern are shown in Figure 4, $b$ (the weighted-average factor, $R_{w p}$, is $6.8 \%$ ). To achieve the best correspondence with the experimental results, the modelling of the XRD patterns was performed in stages. Each stage involved at least 10 iterations. In particular, after selecting the revealed mineral phases during the qualitative X-ray phase analysis, first the scale factor and the background radiation were optimized, then the lattice parameter, the broadening of lines, and then at the final stage - all of the parameters simultaneously. Also optimized were the advance of the sample plane with respect to the X-ray tube focus and the detector, sample displacement in terms of the $2 \theta$ angle, and the Lorentz-polarization (LP) factor. Unlike conventional XPA, in the proposed approach the contents of illite $(6.8 \%)$ and MLIS $(4.1 \%)$ are larger, and the content of kaolinite is smaller (84.6\%). Furthermore, the new approach detected chlorite $(3.5 \%)$ and montmorillonite $(1.0 \%)$ (Figure 4, $b$ ).

As demonstrated by the experimental research, when the conventional procedure was used for the measurement of the XRD patterns of pelitic fraction, the intensities of separate reflections, e.g. of kaolitite, at the scattering angles $19-22^{\circ}, \sim 35^{\circ}, \sim 37^{\circ}, \sim 45^{\circ}$ and $\sim 55^{\circ}$, were much lower than the tabular data (Figure 3,a). The mentioned discrepancy is primarily related to the presence in the mount of a crystallographic texture formed during the deposition of the pelitic fraction on the substrate surface. According to the XPA and SEM data, it can be asserted that the kaolinite crystallite $\{001\}$ planes of the elementary lattice lie parallel to the glass substrate. As a result, this process leads to a strong growth in the intensity of the $\{001\}$ diffraction maxima during the measurement (Figure 3,a). The revealed discrepancy between the experimental and tabular values in terms of reflection intensities severely complicates the processing of an XRD pattern and often yields incorrect results. This problem was eliminated in the new procedure for the measurement of clay minerals.

\section{Discussions}

When the new approach was applied in measuring XRD patterns, the qualitative phase analysis not only revealed kaolinite, illite and MLIS, but also detected small-content clay minerals. In particular, in pelitic fraction chlorite (reflection at $6.2^{\circ}$ ) and montmorillonite (reflection at $7.3^{\circ}$ ) were found (Figure 4, $b$ ). Detection of smallcontent clay minerals is directly associated with the use of inclination measurement of pelitic fractions. As demonstrated by the SEM studies, montmorillonite and chlorite grains are characterized by a very small size, much smaller that kaolinite's flaky crystallites. When a pelitic fraction is deposited, montmorillonite and chlorite are most often located between kaolinite flakes (Figures 2, $a, 3, b$ ). In the case of conventional measurement, as a result of the incidence of an $\mathrm{X}$-ray on the mount it may be partially superposed by kaolinite's lamellar grains. This process leads to the absence of the diffraction maxima of montmorillonite and chlorite in the XRD pattern. However, when the new technique, using the azimuthal inclination of the oriented mount with respect to the incident $\mathrm{X}$-ray beam ( $\mathrm{Z}$ axis), was applied for XRD pattern measurement, montmorillonite and chlorite reflections emerged and became stronger at large inclination angles.

The revealed quantitative ratios of clays in the samples were validated using the Bogue procedure proposed in the work [5]. According to this approach, the content of clay minerals is theoretically evaluated from the data for rock-forming oxides found by XRF. In particular, illite's weight fraction is estimated according to the formula: $w_{\text {illite }}=C_{K_{2} O} O \frac{2 M(\text { Illite })}{M\left(K_{2} O\right)}$, and kaolinite's weight fraction - according to the equation: $w_{\text {Kaolin }}=\left(C_{\mathrm{Al}_{2} \mathrm{O}_{3}}-C_{K_{2} \mathrm{O}} \frac{M\left(\mathrm{Al}_{2} \mathrm{O}_{3}\right)}{M_{\text {Illite }} \frac{2}{3}}-\quad C_{\mathrm{Na}_{2} \mathrm{O}} \times\right.$ $\times \frac{2 M\left(\mathrm{Al}_{2} \mathrm{O}_{3}\right)}{\left.0.3 M_{\mathrm{Na}_{2} \mathrm{O}}\right)} \frac{M_{\text {Kaolin }}}{M\left(\mathrm{Al}_{2} \mathrm{O}_{3}\right)}$ [5]. Here $C_{i}$ is the weight fraction of oxides in a mineral (phase) according to the XRF data, $M_{i}$ is the molar mass of a mineral. Following these formulae, the theoretical evaluation of kaolitite's volume fraction accord- 
ing to the XRF data, yields a value of $85.4 \%$, and for illite's volume fraction $-6.5 \%$. The obtained weight fraction values for clay minerals correlate rather well with the results of the general XPA. At the same time, when quantitatively comparing the ratio of clays in the pelite fraction, a new approach to recording diffractograms and their further analysis gives a better match compared to traditional XRF.

Thus, in the proposed XPA approach an intensive and parallel X-ray beam is used that increases the detection limit, and the azimuthal inclination of the oriented clay mount suppresses the crystallographic texture effects during measurements. As a result, the poorly visible reflections of small-content secondary phases are enhanced, and the untypically high intensities of certain diffraction maxima caused by the oriented occurrence of crystallite-grains to the substrate are suppressed. All of the above increases the accuracy of the quantitative calculations and detection of small-content clay minerals.

\section{REFERENCES}

1. Bish D.L., Howard S.A. Quantitative Phase Analysis Using the Rietveld Method. Journal of Applied Crystallography, 1988, Vol. 21, Issue 2, pp. 86-91. DOI: $10.1107 / \mathrm{S} 0021889887009415$.

2. Drits V.A., Varaxina T.V., Sakharov B.A., Plancon A. A Simple Technique for Identification of One-Dimensional Powder X-Ray Diffraction Patterns for Mixed-Layer IlliteSmectites and other Interstratified Minerals. Clays and Clay Minerals, 1994, Vol. 42, pp. 382-390. DOI: 10.1346/ CCMN.1994.0420402.

3. Rietveld H.M. A Profile Refinement Method for Nuclear and Magnetic Structures. Journal of Applied Crystallography, 1969, Vol. 2, pp. 65-71. DOI: 10.1107/ S0021889869006558.

4. Ufer K., Kleeberg R., Bergmann J., Dohrmann R. Rietveld Refinement of Disordered Illite-Smectite MixedLayer Structures by a Recursive Algorithm. II: PowderPattern Refinement and Quantitative Phase Analysis. Clays and Clay Minerals, 2012, Vol. 60, pp. 535-552. DOI: 10.1346/CCMN.2012.0600508

5. Zeng Z., Lu H., Zhao Y., Qin Y. Analysis of the Mineral Compositions of Swell-Shrink Clays from Guangxi Province, China. Clays and Clay Minerals, 2020, Vol. 68, pp. 161-174. DOI: 10.1007/s42860-019-00056-7.

\section{Conclusions}

As a result of increasing the detection limit by obtaining an averaged XRD pattern in a parallel beam with an increased X-ray intensity and a longer exposure time per point, for the first time the phase composition of clay minerals with a small volume fraction has been revealed and their volume fractions have been quantitatively evaluated. Unlike conventional XPA that is implemented in a divergent beam, the data about the type and content of clay minerals found by the modified XPA procedure are in better agreement with the SEM and XRF data. The obtained results open new opportunities for an in-depth study into the processes of sedimentogenesis, lithogenesis and diagenesis. Furthermore, the refinement of the geological model based on the data from the XPA study of the pelitic fraction will enable effecting a predictable development of oil and gas fields, as well as increasing the producible oil index.

\section{СПИСОК ИСТОЧНИКОВ}

1. Bish D.L., Howard S.A. Quantitative Phase Analysis Using the Rietveld Method // Journal of Applied Crystallography. 1988. Vol. 21. Issue 2. P. 86-91. DOI: 10.1107/S0021889887009415.

2. Drits V.A., Varaxina T.V., Sakharov B.A., Plancon A. A Simple Technique for Identification of One-Dimensional Powder X-Ray Diffraction Patterns for Mixed-Layer IlliteSmectites and other Interstratified Minerals // Clays and Clay Minerals. 1994. Vol. 42. P. 382-390. DOI: 10.1346/ CCMN.1994.0420402.

3. Rietveld H.M. A Profile Refinement Method for Nuclear and Magnetic Structures // Journal of Applied Crystallography. 1969. Vol. 2. P. 65-71. DOI: 10.1107/ S0021889869006558.

4. Ufer K., Kleeberg R., Bergmann J., Dohrmann R. Rietveld Refinement of Disordered Illite-Smectite MixedLayer Structures by a Recursive Algorithm. II: PowderPattern Refinement and Quantitative Phase Analysis // Clays and Clay Minerals. 2012. Vol. 60. P. 535-552. DOI: 10.1346/ CCMN.2012.0600508.

5. Zeng Z., Lu H., Zhao Y., Qin Y. Analysis of the Mineral Compositions of Swell-Shrink Clays from Guangxi Province, China // Clays and Clay Minerals. 2020. Vol. 68. P. 161-174. DOI: 10.1007/s42860-019-00056-7.

\section{INFORMATION ABOUT THE AUTHORS ИНФОРМАЦИЯ ОБ АВТОРАХ}

Vil D. Sitdikov, Doctor of Physical and Mathematical Sciences, Head of the Special Methods of Core Research Laboratory, RN-BashNIPIneft LLC, Ufa, Russia

Ситдиков Виль Даянович, доктор физико-математических наук, заведующийлабораторией спеииальных методов исследования керна, ООО «РН-БашНИПИнефть», Уфа, Россия

SitdikovVD@bnipi.rosneft.ru 
Artem A. Nikolaev, Chief Specialist of the Special Methods of Core Research Laboratory, RN-BashNIPIneft LLC, Ufa, Russia

Николаев Артем Анатольевич, главный специиалист лаборатории специальных методов исследования керна, ООО «РН-БашНИПИнефть», Уфа, Россия

NikolaevAA1@bnipi.rosneft.ru

Ekaterina A. Kolbasenko, Senior Specialist of the Special Methods of Core Research Laboratory, RN-BashNIPIneft LLC, Ufa, Russia

Колбасенко Екатерина Алексеевна, стариий специалист лаборатории специильных методов исследования керна, ООО «РН-БашНИПИнефть», Уфа, Россия

KolbasenkoEA@bnipi.rosneft.ru

Artem K. Makatrov, Candidate of Engineering Sciences, Head of Core and Reservoir Fluids Research Directorate, RN-BashNIPIneft LLC, Ufa, Russia

Макатров Артем Константинович, кандидат технических наук, начальник управления исследования керна и пластовых флюидов, ООО «РН-БашНИПИнефть», Уфа, Россия

MakatrovAK@bnipi.rosneft.ru

Andrey V. Malinin, Candidate of Engineering Sciences, Deputy General Director for Laboratory Research, RN-BashNIPIneft LLC, Ufa, Russia

Малинин Андрей Владимирович, кандидат технических наук, заместитель генерального директора по исследованиям, ООО «РН-БашНИПИнефть», Уфа, Россия

MalininAV@bnipi.rosneft.ru

Статья поступила в редакичию 27.08.2021; одобрена после рецензирования 01.09.2021; принята к публикаичи 03.09.2021.

The article was submitted 27.08.2021; approved after reviewing 01.09.2021; accepted for publication 03.09.2021. 